\title{
Sehat Jiwa pada Masa Pandemi Covid-19 Di RT 51 Kelurahan Kenali Besar Kecamatan Alam Barajo
}

\author{
Vevi Suryenti Putri ${ }^{1}$, Siti Makhruzah ${ }^{2}$, Rd. Hari Periza ${ }^{3}$ \\ Program Studi Ilmu Keperawatan, Sekolah Tinggi Ilmu Kesehatan BaiturrahimJambi \\ Email :vevisuryentiputri.2010@gmail.com
}

\section{Submitted:12/06/2021 Accepted: 14/06/2021 Published:28/06/2021}

\begin{abstract}
The 2019 coronavirus disease pandemic (COVID-19) has not only threatened physical health, but has also threatened the mental health of many people. Some of the mental disorders that often arise today are emotional, stress, excessive anxiety, depression, and so on. Anxiety and mental disorders will then cause an imbalance in the brain, which in turn results in a psychic disorder, also known as psychosomatic.To increase public knowledge about covid -19 and understand mental health, and steps in maintaining mental health during the Covid-19 pandemic as an effort to change behavior so that later it can improve the degree of public health in RT 51 Kelurahan Kenali Besar Jambi City, interventions carried out are provide health education about mental health by thinking optimistically in the face of the Covid-19 pandemic. The method used in education is observation, counseling and evaluation.After health education was carried out for residents of RT 51, Kenali Besar Village, $100 \%$ were able to explain the meaning of mental health by thinking optimistically in the face of the Covid-19 pandemic.
\end{abstract}

Keywords: Covid-19, mental health

\begin{abstract}
Abstrak
Pandemi penyakit virus corona2019 (COVID-19) bukan hanya mengancam kesehatan fisik, tetapi juga telah mengancam kesehatan mental banyak orang.Beberapa gangguan mental yang kerap timbul dewasa ini misalnya mudah terbawa emosi, stres, cemas berlebihan, depresi, dan sebagainya.Kecemasan dan gangguan mental ini kemudian akanmenimbulkan ketidakseimbangan di otak, yang pada akhirnya timbul menjadi gangguan psikis, atau disebut juga psikosomatik. Untuk meningkatkan pengetahuan masyarakat tentang covid -19 dan memahami sehat jiwa, dan langkah-langkah dalam menjaga kesehatan jiwa saat pandemi Covid-19sebagai upaya untuk perubahan perilaku sehingga nantinya dapat meningkatkan derajat kesehatan masyarakat di RT 51 Kelurahan Kenali Besar kota jambi, Intervensi yang dilakukan yaitu memberikan pendidikan kesehatan tentang Sehat Jiwa dengan cara berfikir secara Optimis dalam menghadapi masa pandemi Covid-19. Metode yang digunakan dalam pengabdian ini adalah obserevasi, penyuluhan dan evaluasi.Setelah dilakukan pendidikan kesehatan pada warga RT 51 Kelurahan Kenali Besar didapatkan hasil $100 \%$ dapat menjelaskan pengertian sehat jiwa dengan cara berfikir secara optimis dalam menghadapi masa pandemi Covid-19.
\end{abstract}

Kata Kunci : Covid-19, Sehat Jiwa 


\section{PENDAHULUAN}

Kesehatan jiwa menurut WHO (World Health Organization) adalah ketika seseorang tersebut merasa sehat dan bahagia, mampu menghadapi tantangan hidup serta dapat menerima orang lain sebagaimana seharusnya serta mempunyai sikap positif terhadap diri sendiri dan orang lain. Kesehatan jiwa adalah kondisi dimana seorang individu dapat berkembang secara fisik, mental, spiritual, dan sosial sehingga individu tersebut menyadari kemampuan sendiri, dapat mengatasi tekanan, dapat bekerja secara produktif, dan mampu memberikan kontribusi untuk komunitasnya. Kondisi perkembangan yang tidak sesuai pada individu disebut gangguan jiwa (UU No.18 tahun2014).

Menurut Keliat, dkk dalam Prabowo (2014), kesehatan jiwa suatu kondisi mental sejahtera yang memungkinkan hidup harmonis dan produktif sebagian yang utuh dari kualitas hidup seseorang, dengan memperhatikan semua segi kehidupan manusia dengan ciri menyadari sepenuhnya kemampuan dirinya. Mampu menghadapi stress kehidupan dengan wajar, mampu bekerjadengan produktif dan memenuhi kebutuhan hidupnya, dapat berperan serta dalam lingkungan hidup, menerima dengan baik apa yang da pada dirinya dan merasa nyaman dengan orang lain. Menurut Videbeck (2008) menjelaskan kesehatan jiwa suatu kondisi sehat emosional, psikososial, psikologis dan sosial yang terlihat dari hubungan interpersonal yang memuaskan,perilaku dan koping yang efektif, konsep diri yang positif dan stabilan emosional.

Kesehatan adalah keadaan sejahtera dari badan, jiwa, dan sosial yang memungkinkan hidup produktif secara sosial dan Ekonomi. Jiwa (mental) adalah hasil proses aktivitas otak yang bermanifestasi dalam proses pikir, perasaan dan tingkah laku. Bila terjadi kelainan/gangguan dalam otak, jiwa akan terganggu yang tampak dalam kelainan berpikir, berperasaan dan bertingkah laku Pengetahuan mengenai fenomenologi jiwa itu diperoleh melalui ilmu-ilmu perilaku, neurologi, genetika, dll (misalnya Ilmu Psikiatri) (Depkes RI tahun 2014).

Menurut WHO (2020), munculnya pandemi menimbulkan stres pada berbagai lapisan masyarakat. Meskipun sejauh ini belum terdapat ulasan sistematis tentang dampak COVID-19 terhadap kesehatan jiwa, namun sejumlah penelitian terkait pandemi (antara lain flu burung dan SARS) menunjukkan adanya dampak negatif terhadap kesehatan mental penderitanya.

Penelitian pada penyintas SARS menunjukkan bahwa dalam jangka menengah dan panjang, $41-65 \%$ dari penyintas mengalami berbagai macam gangguan psikologis (Maunder, 2009). Sebuah penelitian di Hong Kong menunjukkan bahwa masalah psikologis pada penyintas SARS tidak berkurang dalam kurun waktu satu tahun setelah kejadian. Bahkan, diperkirakan $64 \%$ dari penyintas berpotensi mengalami gangguan psikiatrik (Lee, dkk., 2007).

Faktor risiko terbesar untuk mengalami berbagai distres psikologis terdapat pada perempuan dan tenaga kesehatan. Sebuah penelitian yang juga dilakukan di Hong Kong bahkan menunjukkan bahwa 30 bulan paskainfeksi SARS, $25.6 \%$ dari penyintas mengalami Post Traumatic Disorders (PTSD) dan $15.6 \%$ mengalami gangguan depresi. Secara rata-rata, setidaknya $30 \%$ penyintas mengalami salah satu dari gejala tersebut (Mak dkk., 2009).

Masalah kesehatan jiwa dapat ditemukan juga pada individu baik di Rumah Sakit maupun dikomunitas yang mengalami masalah fisik.Pelayanan kesehatan jiwa yang dilakukan adalah upaya preventif gangguan jiwa. Individu dengan masalah fisik adalah orang dengan masalah kejiwaan yang beresiko mengalami gangguan jiwa yang memerlukan asuhan keperawatan jiwa. 
Diagnosa keperawatan jiwa yang sering ditemukan terkait diagnosis fisik yang dialami masa pandemi covid-19 adalah ansietas, harga diri rendah situasional, ketidak efetifan koping individu. Asuhan Keperawatan diberikan bersamaan antara diagnosis keperawatan fisik dan diagnosis resiko gangguan jiwa dengan tujuan memberikan kemampuan masalah keperawatan fisik dan secara kebersamaan melakukan cara merawat resiko gangguan jiwa sehingga diharapkan tidak terjadi gangguan jiwa (Keliat, 2019).

Pandemi COVID-19 merupakan bencana non alam yang dapat memberikan dampak pada kondisi kesehatan jiwa dan psikososial setiap orang. Sampai dengan tanggal 25 Maret 2020, dilaporkan total kasus konfirmasi COVID-19 sejumlah 414.179 dengan 18.440 kematian (CFR 4,4\%) yang dilaporkan di 192 negara/wilayah. Di antara kasus tersebut, sudah ada beberapa petugas kesehatan yang dilaporkan terinfeksi COVID-19. Pada tanggal 12 April 2020, Indonesia melaporkan kasus konfirmasi COVID-19 sebanyak 4.241 kasus (Kemenkes, 2020).

Coronaviruses (CoV) adalah keluarga besar virus yang menyebabkan penyakit mulai dari flu biasa hingga penyakit yang lebih parah seperti Sindrom Pernafasan Timur Tengah (MERS-CoV) dan Sindrom Pernafasan Akut Parah (SARS-CoV) (Covid19.go.id)

Coronavirus merupakan virus RNA strain tunggal positif, berkapsul dan tidak bersegmen. Coronavirus tergolong ordo Nidovirales, keluarga Coronaviridae. Coronaviridae dibagi dua subkeluarga dibedakan berdasarkan serotipe dan karakteristik genom.Terdapat empat genus yaitu alpha coronavirus, betacoronavirus, deltacoronavirus dan gamma coronavirus (Burhan, Erlina, dkk. 2020).

Penyakit Coronavirus 2019 (COVID-19) adalah virus corona jenis baru yang ditemukan pada tahun 2019 dan belum pernah teridentifikasi pada manusia.Virus corona adalah zoonosis, artinya ditularkan antara hewan dan manusia.Investigasi terperinci menemukan bahwa SARS-CoV ditularkan dari kucing luwak ke manusia dan MERS-CoV dari unta dromedaris ke manusia.Beberapa coronavirus yang dikenal beredar pada hewan yang belum menginfeksi manusia (Covid19.go.id).

Tanda-tanda umum infeksi termasuk gejala pernapasan, demam, batuk, sesak napas dan kesulitan bernafas,diare, hilang penciuman. Pada kasus yang lebih parah, infeksi dapat menyebabkan pneumonia, sindrom pernapasan akut, gagal ginjal, dan bahkan kematian (Covid19.go.id).

Pandemi Covid 19 telah menyebar ke berbagai negara pada waktu yang berbeda, Tergantung Sistem Politik, Kesiapan Pelayanan Kesehatan dan Ekonomi. Perkembangan kasus Covid-19 di Dunia Kasus terkonfirmasi: 8,974,795 dan mengalami Kematian: 469,159 sedangkan covid di Indonesia Terkonfirmasi: 50,187, Dalam perawatan: 20,118, dan Sembuh: 20,448 serta Meninggal: 2,620 (Sinaga, 2020).

Data covid 19 Kabupaten Kota di Provinsi Jambi yang konfim 446 dan proses 172, suspek 82, sembuh, 265 dan kematian 9 orang. Sedangkan data Kota Jambi kum 463, konfirm 37, sembuh 24 dan kematian 1 orang (Humas Protokol Jambi, 2020)

Di akhir bulan Desember 2019 , masyarakat ditakutkan dengan adanya wabah virus yang dikenal dengan sebutan COVID-19 dan pertama kali ditemukan di kota Wuhan, Cina. Virus ini menular dengan cepat dan telah menyebar ke wilayah lain di Cinda dan ke beberapa negara, termasuk Indonesia. Koronavirus adalah kumpulan virus yang bisa menginveksi system pernapasan. Pada banyak kasus, virus ini hanya menyebabkan infeksi pernapasan ringan, seperti flu. Namun, virus ini juga bisa menyebabkan infeksi pernapasanberat,

Data statistik yang dikemukakan oleh (WHO) (2012) menyebutkan 
bahwasekitar 450 juta orang di dunia mengalami masalah gangguan kesehatan jiwa.Sepertiga diantaranya terjadi di Negara berkembang. Data yang ditemukan oleh peneliti di Harvard University dan University College London, mengatakan penyakit kejiwaan pada tahun 2016 meliputi $32 \%$ dari semua jenis kecacatan diseluruh dunia. Angka tersebut meningkat dari tahun sebelumnya (VOA Indonesia,2016).

Sama dengan Negara lain hingga saat ini Indonesia masih berupaya melawan Virus Corona. Jumlah kasus virus Corona terus bertambah dengan beberapa melaporkan kesembuhan, tapi tak sedikit yang meninggal. Usaha penanganan dan pencegahan terus dilakukan demi melawan COVID-19 dengan gejala mirip flu.Kasus Virus Corona diketahui lewat penyakit misterius yang melumpuhkan Kota Wuhan, China. Tragedi pada akhir 2019 tersebut terus berlanjut hingga penyebaran virus Corona mewabah ke seluruh dunia. Dikutip dari $C N N$, berikut beberapa hal yang wajib diketahui seputar perkembangan oronavirus, yang biasa disebutvirusCorona atau COVID-19, hingga mewabah dan jadi pandemi.

Pandemi penyakit virus corona 2019 (COVID-19) bukan hanya mengancam kesehatan fisik, tetapi jugatelah mengancam kesehatan mental banyak orang. Betapa tidak, penyakit yang telah menelan 53.292 korban jiwa di seluruh dunia hingga 3 April 2020 ini telah menimbulkan banyak kekhawatiran di kalangan masyarakat. Setiap menit, masyarakat selalu dihujani oleh berita dan informasi seputar COVID-19, baik melalui TV, media sosial, serta internet, maka tak heran jika banyak masyarakat mengalami gangguan mental seperti rasa kekhawatiran yang berlebihan di tengah pandemi penyakit yang ditimbulkan oleh virus corona tersebut.

Gangguan mental yang kerap timbul dewasa ini misalnya mudah terbawa emosi, stres, cemas berlebihan, depresi, dan sebagainya. Kecemasan dan gangguan mental ini kemudian akan menimbulkan ketidakseimbangan di otak, yang pada akhirnya timbul menjadi gangguan psikis, atau disebut juga psikosomatik. Ketika seseorang mengalami gejala psikosomatik, maka ia bisa merasakan gejala seperti penyakit COVID-19, yakni merasademam, pusing, atau sakit tenggorokan, padahal suhu tubuhnya normal.

Pandemi Covid 19 telah menyebar ke berbagai negara pada waktu yang berbeda, Tergantung Sistem Politik, Kesiapan Pelayanan Kesehatan dan Ekonomi. Perkembangan kasus Covid-19 di Dunia Kasus terkonfirmasi: 8,974,795 dan mengalami Kematian: 469,159 sedangkan covid di Indonesia Terkonfirmasi: 50,187, Dalam perawatan: 20,118, dan Sembuh: 20,448 serta Meninggal: 2,620 (Sinaga, 2020).

Setiap orang perlu menjaga kesehatan mentaluntuk dapat mengindari keluhan fisik yang muncul akibat stres. Karena, ketika seseorang stres, maka sistem imun dalam tubuh akan berkurang. Ini akan menyebabkan tubuh mudah terserang penyakit. Menyadari bahwa kecemasan akibat COVID-19 telah meliputi banyak masyarakat, maka World Health Organization (WHO) pada Maret 2020 merilis panduan bagi masyarakat untuk sama-sama menjaga kesehatan mental (Koentiaraningrat,2009)

Sebelum dilakukan pendidikan kesehatan pada warga, tim pengabdian melakukan pengkajian, pada warga RT. 51 Kelurahan Kenali Besar Kecamatan Alam Barajo, dari hasil wawancara beberapa warga megatakan "mereka merasa pesimis dan cemas kapan wabah pandemi ini akan berakhir dan mereka merasa takut dalam melakukan aktivitas sehari-hari diakrenakan takut tertular virus Covid-19.

Dari hasil observasi di atas, mahasiswa merasa perlu memberikan penyuluhan kesehatan tentang pentingnya menjaga kesehatan jiwa saat pandemi 
Covid-19 di RT. 51 Kelurahan Kenali Besar Kecamatan Alam Barajo.

\section{TARGET DAN LUARAN}

\section{A. Target}

Dari permasalahan mitra terdapat permsalahan di RT 51 Kelurahan Kenali Besar Kecamatan Alam Barajo salahsatunya adalah kurangnya pengetahuan terhadap covid 19, maka dari itu dilakukan kegiatan untuk mengatasi permasalahan tersebut yaitu dengan mengadakan pendidikan kesehatan tentang sehat jiwa dengan harapan agar masyarakat mau mengaplikasikan informasi yang telah disampaikan dengan berfikir secara optimis dalam mengahadapi masa pandemi Covid-19.

Rencana tindak lanjut dari permasalahan tersebut, tim berkooordinasi dengan puskesmas setempat pada unit pemegang program jiwa untuk memberikan pendidikan kesehatan berkesinambungan setiap 6 bulan kepada warga.

\section{B. Luaran}

Hasil pendidikan kesehatan ini diharapkanwarga mampu mengetahuidan memahami tentang pentingnya sehat jiwa dalam masa pandemic covid-19

a. Memahami tentang pengrtian covid 19

b. Memahami cara penularan covid-19

c. Memahami tetang cara pencegahan penularan covid-19

d. Memahami tentang pentalaksaan dalam pengobatan covid-19

e. Memahami tentang konsep sehat jiwa

f. Memahami prinsip agar tetap sehat jiwa dalam kondisi apapun

g. Mengajarkan berfikir positif untuk menjaga kesehatan jiwa

\section{METODE PELAKSANAAN}

Kegiatan penyuluhan ini dikemas dengan bertatap langsung dengan warga, suasana yang santai akan tetapi proses diskusi dua arah antara penyaji dan warga yang mengikuti penyuluhan. Kegiatan juga berjalan dengan baik dan lancar. Penyaji menyampaikan penyuluhan tentang covid 19 dan sehat jiwa dalam masa pandemi Covid-19. Kegiatan ini dilaksanakan pada bulan Desember2020. Dengan jumlah peserta20 orang warga RT 51 Kelurahan Kenali Besar Kecamatan Alam Barajo, Media yang digunakan adalah lembar balik dan leaflet yang dibagikan ke warga.

Tahapan pelaksanaan kegiatan pengabdian kepada masyarakat ini adalah sebagai berikut:

\section{Persiapan}

a) Survey awal permasalahan pada lahan yang akan dilakukan pengebdian masyarakat.

b) Menyusun proposal kegiatan pengabdian kepada masyarakat. Pengadaan Poster/media

c) Menyiapkan materi/bahan presentasi tentang konsep sehat jiwa pada masa pandemic covid-19

\section{Pelaksanaan Kegiatan}

a) Perkenalan, diskusi tim serta menjelaskan kegiatan yang akan dilakukan

b) Edukasi pada warga tentang pentingnya menjaga kesehatan jiawa pada masa pandemic covid-19 melalui media infocus, poster dan leafleat.

c) Demonstrasi tentang cara pencegahan peularan covid 19

d) Tanya jawab/ diskusi

e) Penutupan

\section{Monitoring dan Evaluasi}

Monitoring dan evaluasi (Monev) dilakukan secara langsung kepada sasaran. Cakupan Monev dalam kegiatan ini meliputi monev perencanaan dan pelaksanaan dan evaluasi hasil.

\section{HASIL DAN PEMBAHASAN}

Pendidikan kesehatan dilakukan dengan menjelaskan pengertian sehat jiwa, manfaat menjaga kesehatan jiwa, menjaga kesehatan jiwa yang baik dan benar dalam kehidupan sehari-hari, dan langkah-langkah dalam menjaga kesehatan 
jiwa saat Pandemi Covid-19. Pada proses tanya jawab menanyakan bagaimana pemahaman masyarakat Rt 51 Kelurahan Kenali Besar Kecamatan Alam Barajo tentang sehat jiwa, manfaat menjaga kesehatan jiwa, menjaga kesehatan jiwa yang baik dan benar dalam kehidupan sehari-hari, dan langkah-langkah dalam menjaga kesehatan jiwa saat Pandemi Covid-19 dan juga memberikan kesempatan kepada mereka bilamana masih ada hal yang belum dipahami tentang sosialisasi sehat jiwa dalam masa pandemi Covid-19.

Hasil pengkajian yang telah di analisis untuk menyelesaian permasalahan yang didapat di RT 51 Kelurahan Kenali Besar Kecamatan Alam Barajo disepakati untuk menyelesaikan kegiatan pendidikan kesehatan tentang Seha Jiwa Pada Masa Pandemi Covid-19 dengan cara berfikir secara optimis..

Secara Keseluruhan Kegiatan Berjalan dengan baik sesuai dengan yang direncanakan.Semua pihak dapat bekerjasama dengan baik. Dengan dilaksanakannya kegiatan Penyuluhan, Seluruh peserta masyarakat termotivasi untuk tetap berfikir secara optimis dalam masa pnademi Covid-19. Setelah dilakukan pendidikan kesehatan pada warga RT 51Kelurahan Kenali Besar Kecamatan Alam Barajo didapatkan hasil dari 20 orang (100\%) warga sehat jiwa, manfaat menjaga kesehatan jiwa, menjaga kesehatan jiwa yang baik dan benar dalam kehidupan sehari-hari, dan langkah-langkah dalam menjaga kesehatan jiwa saat Pandemi Covid-19 yang saat ini menjadi permasalahan didunia dan di masyarakat sekitar RT 51 Kelurahan Kenali Besar Kecamatan Alam Barajo.

Berdasarkan hasil penelitian Winurini Sulis, yang berjudul "Permasalahan Kesehatan Mental Akibat Pandemi Covid-19" (2020) menunjukkan hasil Permasalahan kesehatan mental, seperti cemas, depresi, dan trauma karena Covid-19 dirasakan oleh sebagian besar masyarakat Indonesia. Beberapa faktor risiko utama adalah jarak dan isolasi sosial, resesi ekonomi, stres dan trauma pada tenaga kesehatan, serta stigma dan diskriminasi.Terhadap permasalahan ini, pemerintah telah meluncurkan layanan Sejiwa untuk membantu menangani ancaman psikologi masyarakat akibat pandemi Covid-19.Selain itu, pemerintah juga meluncurkan Buku Pedoman Dukungan Kesehatan Jiwa dan Psikososial pada Pandemi Covid-19, di samping berupaya mengembangkan Desa Siaga Covid-19.

Sedangkan Ridlo Ilham Akhsanu yang berjudul "Pandemi Covid-19 dan Tantangan Kebijakan Kesehatan Mental di Indonesia" (2020) menunjukkan hasil Kebijakan kesehatan mental di Indonesia harus mengoptimalkan integrasi layanan kesehatan mental. Pendekatan berbasis masyarakat dapat memperluas cakupan pelayanan kesehatan mental pada masa Pandemi COVID-19. Pemerintah harus mengintegrasikan layanan kesehatan mental ke dalam layanan berbasis masyarakat sebagai cara untuk memastikan cakupan universal pelayanan kesehatan mental. Model pemberdayaan partisipatif dan bottom-up menjadi pilihan yang rasional, untuk mengatasi masalah sumber daya dan stigma sebagai penghalang keberhasilan program kesehatan mental di Indonesia.

Penelitian Norhapifah Hestri, yang berjudul "Pentingnya Menjaga Kesehatan Jiwa Saat Pandemi Covid-19 Dilingkungan Masyarakat RT 30 Kelurahan Air Hitam, Samarinda, kalimantan Timur" (2020) menunjukkan hasil Setiap orang perlu menjaga kesehatan mental untuk menghindari keluhan fisik yang muncul akibat stres. Karena, ketika seseorang stres, maka sistem imun dalam tubuh akan berkurang. Ini akan menyebabkan tubuh mudah terserang penyakit. Menyadari bahwa kecemasan akibat COVID-19 telah meliputi banyak masyarakat, maka World Health Organization (WHO) pada Maret 
2020 merilis panduan bagi masyarakat untuk sama-sama menjaga kesehatan mental. Caranya ialah dengan melakukan beberapa hal berikut: Cobalah berempati, Kurangi stigma negatif terhadap pasien COVID-19, Batasi diri dari paparan berita dan media sosial, Lindungi diri sendiri dan keluarga, Berikan dukungan pada tenaga medis, Saling mendukung sesama, Olahraga Teratur, Menerapkan pola makan sehat.

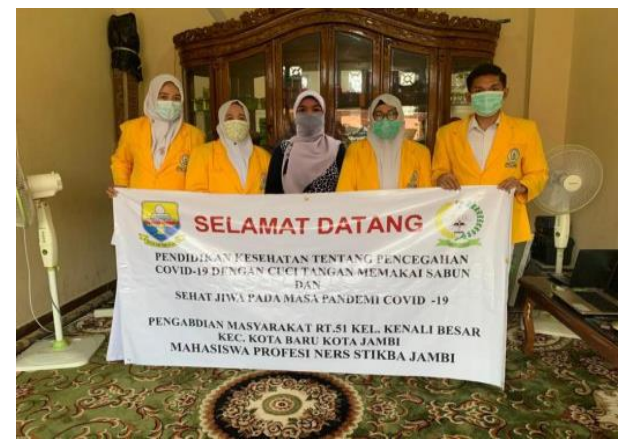

Gambar 1. Foto bersama sebelum kegiatan dilakukan

Kesehatan mental merupakan aspek penting dalam mewujudkan kesehatan yang menyeluruh.Namun di sebagian besar negara berkembang, masalah kesehatan mental belum diprioritaskan apabila dibandingkan dengan penyakit menular. Regulasi, kebijakan kesehatan mental dan implementasinya di Indonesia masih diikuti oleh kesenjangan yang luas terkait dengan masalah cakupan dan akses pada pelayanannya (Ayuningtyas, dkk., 2018; Ridlo \& Zein, 2015).

Pada tahun 2020, Hari Kesehatan Mental Sedunia, yang diperingati pada 10 Oktober 2020, mengambil tema "an opportunity to kick-start a massive scale-up in investment in mental health."World Health Organization (WHO) menekankan pada konsekuensi yang ditimbulkan saat kehidupan kita yang telah banyak berubah akibat pandemi COVID19. Penekanan lain adalah mendorong negara-negara di dunia untuk memberikan perhatian lebih pada kesehatan mental. Sebagai salah satu sektor yang paling terdampak akibat pandemi, kesehatan mental merupakan salah satu bidang kesehatan masyarakat yang paling terabaikan. Padahal, hampir 1 miliar orang hidup dengan gangguan mental, 3 juta orang meninggal setiap tahun akibat penggunaan alkohol yang berbahaya, dan 1 orang meninggal setiap 40 detik karena bunuh diri. Saat ini, miliaran orang di seluruh dunia telah terpengaruh oleh pandemi COVID-19, yang berdampak pada buruknya kondisi kesehatan mental masyarakat (Saxena, 2016; World Health Organization, 2020)

Di akhir bulan Desember 2019, masyarakat ditakutkan dengan adanya wabah virus yang dikenal dengan sebutan COVID-19 dan pertama kali ditemukan di kota Wuhan, Cina. Virus ini menular dengan cepat dan telah menyebar ke wilayah lain di Cinda dan ke beberapa negara, termasuk Indonesia. Koronavirus adalah kumpulan virus yang bisa menginveksi system pernapasan.Pada banyak kasus, virus ini hanya menyebabkan infeksi pernapasan ringan, seperti flu. Namun, virus ini juga bisa menyebabkan infeksi pernapasan berat,seperti infeksi paru-paru (pneumonia). Middle-East Respiratory Syndrome (MERS), dan Severe Acute Respiratory Syndrome (SARS).

Pandemi penyakit virus corona 2019 (COVID-19) bukan hanya mengancam kesehatan fisik, tetapi juga telah mengancam kesehatan mental banyak orang.Betapa tidak, penyakit yang telah menelan 53.292 korban jiwa di seluruh dunia hingga 3 April 2020 ini telah menimbulkan banyak kekhawatiran di kalangan masyarakat. Setiap menit, masyarakat selalu dihujani oleh berita dan informasi seputar COVID-19

Coronaviruses $(\mathrm{CoV})$ adalah keluarga besar virus yang menyebabkan penyakit mulai dari flu biasa hingga penyakit yang lebih parah seperti Sindrom Pernafasan Timur Tengah (MERS-CoV) dan Sindrom Pernafasan Akut Parah (SARS-CoV) (Covid19.go.id) 
Coronavirus merupakan virus RNA strain tunggal positif, berkapsul dan tidak bersegmen. Corona virus tergolong ordo Nidovirales, keluarga Coronaviridae. Coronaviridae dibagi dua subkeluarga dibedakan berdasarkan serotipe dan karakteristik genom.Terdapat empat genus yaitu alpha coronavirus, betacoronavirus, deltacoronavirus dan gamma corona virus (Burhan, Erlina, dkk. 2020).

Penyakit

Coronavirus

2019

(COVID-19) adalah virus corona jenis baru yang ditemukan pada tahun 2019 dan belum pernah teridentifikasi pada manusia.Virus corona adalah zoonosis, artinya ditularkan antara hewan dan manusia.Investigasi terperinci menemukan bahwa SARS-CoV ditularkan dari kucing luwak ke manusia dan MERS-CoV dari unta dromedaris ke manusia.Beberapa coronavirus yang dikenal beredar pada hewan yang belum menginfeksi manusia (Covid19.go.id).

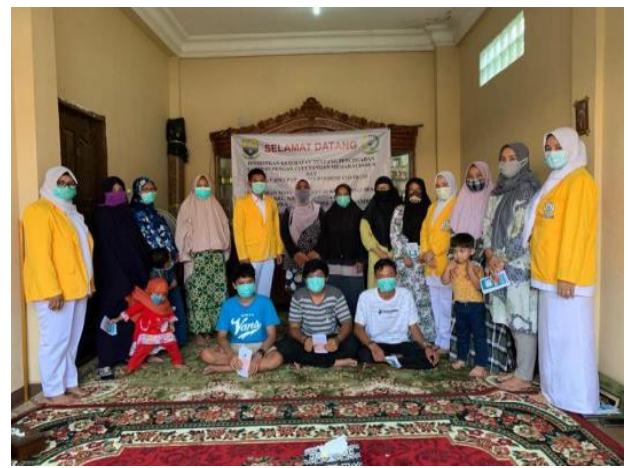

Gambar 2. Sesi 1 foto bersama dengan peserta setelah kegiatan dilakukan

Situasi pandemi COVID-19 mendorong pembahasan yang lebih serius mengenai masifikasi pelayanan kesehatan mental, sebagai salah satu isu penting di dunia. Gangguan kesehatan mental yang sering tersembunyi dari pandangan sesungguhnya memiliki spektrum yang luas (Mawarpury, dkk.,2018). WHO telah mengidentifikasi kesehatan mental sebagai komponen integral dari penanggulangan COVID19 (World Health Organization, 2020b). Melihat permasalahan kesehatan mental dalam konteks situasi pandemi COVID-19.

Beberapa gangguan mental yang kerap timbul dewasa ini misalnya mudah terbawa emosi, stres, cemas berlebihan, depresi, dan sebagainya. Kecemasan dan gangguan mental ini kemudian akan menimbulkan ketidakseimbangan di otak, yang pada akhirnya timbul menjadi gangguan psikis, atau disebut juga psikosomatik. Ketika seseorang mengalami gejala psikosomatik, maka ia bisa merasakan gejala seperti penyakit COVID-19, yakni merasa demam pusing, atau sakit tenggorokan, padahal suhu tubuhnya normal.

Sama dengan Negara lain hingga saat ini Indonesia masih berupaya melawan Virus Corona. Jumlah kasus virus Corona terus bertambah dengan beberapa melaporkan kesembuhan, tapi tak sedikit yang meninggal.Usaha penanganan dan pencegahan terus dilakukan demi melawan COVID-19 dengan gejala mirip flu.Kasus Virus Corona diketahui lewat penyakit misterius yang melumpuhkan Kota Wuhan, China.Tragedi pada akhir 2019 tersebut terus berlanjut hingga penyebaran virus Corona mewabah ke seluruh dunia.Dikutip dari CNN, berikut beberapa hal yang wajib diketahui seputar perkembangan Coronavirus, yang biasa disebut virus Corona atau COVID-19, hingga mewabah dan jadi pandemi.

Setiap orang perlu menjaga kesehatan mental untuk menghindari keluhan fisik yang muncul akibat stres. Karena, ketika seseorang stres, maka sistem imun dalam tubuh akan berkurang. Ini akan menyebabkan tubuh mudah terserang penyakit. Menyadari bahwa kecemasan akibat COVID-19 telah meliputi banyak masyarakat, maka World Health Organization (WHO) pada Maret 2020 merilis panduan bagi masyarakat untuk sama-sama menjaga kesehatan mental (Koentiaraningrat, 2009). 
Masalah kesehatan mental sangat berkaitan dengan hilangnya produktivitas masyarakat dan juga pengendalian pandemi COVID-19. Jika pemerintah tidak memberikan perhatian yang diperlukan pada isu kesehatan mental, khususnya dalam intergrasi implementasi kebijakan terkait penanggulangan pandemi COVID-19, maka potensi kerugian paskapandemi akan semakin besar. Pemerintah harus mengintegrasikan layanan kesehatan mental ke dalam layanan berbasis masyarakat sebagai cara untuk memastikan cakupan universal layanan kesehatan mental. Model pemberdayaan partisipatif dan bottom-up menjadi pilihan yang rasional untuk mengatasi masalah sumber daya dan stigma sebagai penghalang keberhasilan program kesehatan mental di Indonesia.

Melalui kegiatan pengabdian masyarakat ke masyarakat dengan tetap menerapkan protokol COVID-19, dilaksanakan sosialisasi sehat jiwa dalam menghadapi masa Pandemi Covid-19. Pengabdian masyarakat ini dimaksudkan sebagai upaya mengatasi permasalahan diatas dan menambah pengetahuan masyarakat tentang berfikir secara optimis dalam mengahadapi masa pandemi Covid-19. Dalam kegiatan sosialisasi ini, diharapkan masyarakat selalu disiplin menerapkan protokol kesehatan selama pandemi COVID-19, yaitu menggunakan masker, selalu menjaga jarak, sering mencuci tangan menggunakan sabun dengan baik dan benar dan diharapkan masyarakat dapat berfikir secara optimis dalam mengahadapi masa pandemi Covid-19.

Kebijakan kesehatan mental merupakan bagian penting dari kebijakan percepatan penanggulangan pandemi COVID-19.Masalah kesehatan mental sangat berkaitan dengan hilangnya produktivitas masyarakat dan juga pengendalian pandemi COVID-19. Jika kita tidak memberikan perhatian yang diperlukan pada isu kesehatan mental, khususnya dalam intergrasi implementasi kebijakan terkait penanggulangan pandemi COVID-19, maka potensi kerugian paskapandemi akan semakin besar.

Mengintegrasikan layanan kesehatan mental ke dalam layanan berbasis masyarakat sebagai cara untuk memastikan cakupan universal layanan kesehatan mental. Model pemberdayaan partisipatif dan bottom-up menjadi pilihan yang rasional untuk mengatasi masalah sumber daya dan stigma sebagai penghalang keberhasilan program kesehatan mental di Indonesia.

\section{KESIMPULAN DAN SARAN}

\section{Kesimpulan}

Setelah dilakukan kegiatan pengabdian masyarakat, dharapkan masyarakat dapat mengetahuipengertian sehat jiwa, manfaat menjaga kesehatan jiwa, menjaga kesehatan jiwa yang baik dan benar dalam kehidupan sehari-hari, dan langkah-langkah dalam menjaga kesehatan jiwa saat Pandemi Covid-19. Sehingga untuk selanjutnya kualitas kehidupan masyarakat akan meningkat.

\section{Saran}

Setelah dilakukan kegiatan pengabdian masyarakat, dharapkan masyarakat dapat mengetahui pengertian sehat jiwa, manfaat menjaga kesehatan jiwa, menjaga kesehatan jiwa yang baik dan benar dalam kehidupan sehari-hari, dan langkah-langkah dalam menjaga kesehatan jiwa saat Pandemi Covid-19. Sehingga untuk selanjutnya kualitas kehidupan masyarakat akan meningkat.

\section{UCAPAN TERIMAKASIH}

Terimakasih yang tak terhingga kepada Sekolah Tinggi Ilmu Kesehatan Baiturrahim Jambi yang memberikan kemudahan dalam pelaksanaan kegiatan ini. Selain itu penulis juga mengucapkan terimaksih kepada ketua RT. 51 Kelurahan 
Kenali Besar, Kecamatan Alam Barajo Kota Jambi karena telah dengan senang hati menerima dan membantu proses pengabdian masyarakat ini sehingga kegiatan ini bisa terlaksana dan berjalan lancar.

\section{DAFTAR PUSTAKA}

Centers for Disease Control and Prevention(2020). $2019 \quad$ Novel Coronavirus, Wuhan, China.

Citroner, G. Healthline (2020). ChinaCoronavirus Outbreak: CDC IssuesWarning, Multiple Cases in U.S.

Huang, et al.(2020). Clinical features ofpatients infected with 2019 novelcoronavirus in Wuhan, China. TheLancet, 6736(20), pp. 1-10.

Inter-Agency Standing Committee (IASC). IASC Guidelines on Mental Health andPsychosocial Support in Emergency Settings. IASC: Geneva, 2007

International Federation of Red Cross and Red Crescent Societies (IFRC). Mental Healthand Psychosocial Support for Staff, Volunteers and Communities in an Outbreak of NovelCoronavirus. IFRC: Hong Kong, 2020.

IASC Reference Group on Mental Health and Psychosocial Support in EmergencySettings. Mental Health and Psychosocial Support in Ebola Virus Disease Outbreaks: AGuide for Public Health Programme Planners. IASC: Geneva,2015.

Keliat, Budi Anna; Panjaitan;Helena. 2005. Proses Keperawatan Kesehatan Jiwa. Ed.2. Jakarta:EGC.

Norhapifah Hestri. 2020. Pentingnya Menjaga Kesehatan Jiwa Saat Pandemi Covid-19 Dilingkungan Masyarakat RT 30 Kelurahan Air Hitam, Samarinda, kalimantan Timur. Diakses 19 Desember 2020
Ridlo Ilham Akhsanu. 2020. Pandemi Covid-19 dan Tantangan Kebijakan Kesehatan Mental di Indonesia. Diakses 19 Desember 2020

Stuart, Gail W.2007. Buku Saku Keperawatan Jiwa. Jakarta : EGC.

Suliswati, 2005. Konsep Dasar Keperawatan Kesehatan Jiwa. Jakarta :EGC

Wang, et al. (2020). A Novel CoronavirusOutbreak of Global Health Concern.The Lancet, 6736(20), pp. 1-4.

Winurini Sulis. 2020. Permasalahan Kesehatan Mental Akibat Pandemi Covid-19.Diakses 19 Desember 2020

World Health Organization (2020).Coronavirus. World Health Organization (2020). NovelCoronavirus (2019-nCoV). Yosep,Iyus.2007. Keperawatan Jiwa. Jakarta: PT. Refika Aditama 